\title{
Elderly vulnerability: concept development
}

\author{
Vulnerabilidade da pessoa idosa: desenvolvimento de conceito \\ Vulnerabilidad de la persona anciana: desarrollo de concepto
}

\section{Keylla Talitha Fernandes Barbosa' ORCID: 0000-0001-6399-002X \\ Maria das Graças Melo Fernandes' ORCID: 0000-0002-1694-1206}

'Universidade Federal da Paraíba. João Pessoa, Paraíba, Brazil.

How to cite this article: Barbosa KTF, Fernandes MGM. Elderly vulnerability: concept development. Rev Bras Enferm. 2020;73(Suppl 3):e20190897. doi: http://dx.doi.org/10.1590/0034-7167-2019-0897

Corresponding author: Keylla Talitha Fernandes Barbosa E-mail: keyllafernandes@gmail.com

EDITOR IN CHIEF: Antonio José De Almeida Filho ASSOCIATE EDITOR: Hugo Fernandes

Submission: $03-09-2020$

Approval: 06-26-2020

\begin{abstract}
Objective: Propose the concept of vulnerability of the elderly based on the Hybrid Concept Development Model. Method: Methodological study with a qualitative approach, based on the theoretical-methodological framework of the Hybrid Concept Development Model. Initially, an integrative literature review was carried out, followed by empirical collection through semi-structured interviews with 12 professionals. As a method of analysis of the interviews, the Grounded Theory was used. The final analytical phase constituted the interface between theoretical and empirical evidence. Results: When carrying out the theoretical survey, it became possible to outline the attributes, antecedents and consequences of the studied phenomenon. After analyzing the empirical data, two phenomena emerged: Unveiling the multiple changes arising from the human aging process; and Understanding the multiple dimensions of the elderly person's vulnerability construct. Final considerations: The vulnerability of the elderly person consists of a multifaceted construct, in which individual and collective conditions interact with each other.
\end{abstract}

Descriptors: Nursing;Vulnerable Populations; Aged; Concept Formation; Nurses, Public Health.

\section{RESUMO}

Objetivo: Propor o conceito de vulnerabilidade da pessoa idosa com base no Modelo Híbrido de Desenvolvimento de Conceitos. Método: Estudo metodológico com abordagem qualitativa, fundamentada no referencial teórico-metodológico do Modelo Híbrido de Desenvolvimento de Conceito. Inicialmente, realizou-se a revisão integrativa da literatura, seguida por coleta empírica mediante entrevista semiestruturada com 12 profissionais. Como método de análise das entrevistas, utilizou-se a Teoria Fundamentada nos Dados. A fase analítica final constituiu a interface entre as evidências teóricas e empíricas. Resultados: Ao realizar o levantamento teórico, tornou-se possível o delineamento dos atributos, antecedentes e consequências do fenômeno estudado. Após análise dos dados empíricos, dois fenômenos emergiram: Desvelando as múltiplas alterações advindas do processo de envelhecimento humano; e Compreendendo as múltiplas dimensões do constructo da vulnerabilidade da pessoa idosa. Considerações finais: A vulnerabilidade da pessoa idosa consiste em um constructo multifacetado, em que condições individuais e coletivas interagem entre si. Descritores: Enfermagem; Vulnerabilidade em Saúde; Idoso; Formação de Conceito; Análise da Vulnerabilidade.

\section{RESUMEN}

Objetivo: Proponer el concepto de vulnerabilidad de la persona anciana con base en el Modelo Híbrido de Desarrollo de Conceptos. Método: Estudio metodológico con abordaje cualitativo, fundamentado en el referencial teórico-metodológico del Modelo Híbrido de Desarrollo de Concepto. Inicialmente, se realizó la revisión integrativa de la literatura, seguida por recogida empírica mediante entrevista semiestructurada con 12 profesionales. Como método de análisis de las entrevistas, se utilizó la Teoría Fundamentada en los Datos. La fase analítica final constituyó la interfaz entre las evidencias teóricas y empíricas. Resultados: Al realizar el análisis teórico, se volvió posible el delineamiento de los atributos, antecedentes y consecuencias del fenómeno estudiado. Después del análisis de los datos empíricos, dos fenómenos emergieron: Desvelando las múltiples alteraciones advenidas del proceso de envejecimiento humano; y Comprendiendo las múltiples dimensiones del constructo de la vulnerabilidad de la persona anciana. Consideraciones finales: La vulnerabilidad de la persona anciana consiste en un constructo multifacético, en que condiciones individuales y colectivas interaccionan entre si.

Descriptores: Enfermería; Vulnerabilidad en Salud; Anciano; Formación de Concepto; Análisis de la Vulnerabilidad. 


\section{INTRODUCTION}

The population aging process is one of the most relevant demographic transitions. Although the increase in life expectancy is an undeniable advance for humanity, it is considered one of the greatest contemporary challenges, especially among developing countries. It appears that the growth of the elderly population happens quickly and abruptly, making it difficult to provide accommodation in the provision of social, social security and public health services in the face of changes inherent to senescence.

When analyzing the population aging process, it is highlighted that, simultaneously with the demographic transition, significant epidemiological changes occur. In this scenario, it is possible to verify the decline in the incidence of acute communicable diseases in parallel with the increase in cases of chronic non-communicable diseases, typical of more advanced age groups. The pattern of multiple chronic morbidities requires permanent care, constant monitoring, medications for continuous use and periodic exams. In addition, hospital admissions are more frequent and prolonged, requiring more resources from health services ${ }^{(1)}$.

The accelerated growth of the elderly population requires an increasingly urgent adaptation of practices and services aimed at the needs of this age group. Therefore, it is opportune to have an expanded understanding of old age, its peculiarities, including the understanding of physiological, psychological and social aspects. Considering the culture in which the elderly person is inserted, the historical, political and economic conditions that produce diverse social representations and the heterogeneity regarding the health of the elderly is essential to provide comprehensive assistance. Therefore, strictly biological approaches are not adequate to the real demands of this group ${ }^{(2-3)}$.

Considering this premise, the need for new instruments and theoretical models that can guide the practice in relation to the health of the elderly is emphasized, based on the understanding of its breadth and complexity, as well as the physical, psychological, socio-cultural and historical changes, typical of the human aging process. Therefore, in the context of gerontology, the concept of vulnerability is explored, defined as the state of the individual who, for some reason, is unable to take advantage of the opportunities available in different dimensions, in order to improve his well-being or prevent its deterioration. Each individual has a vulnerability threshold that, when crossed, results in illness. It is admitted, therefore, that the individual may present different levels of vulnerability in each of the domains or in the relationship between them, allowing multidimensional analyzes ${ }^{(2-4)}$.

Bearing in mind the complexity and multidimensionality of vulnerability, there is a need to carefully elucidate the meaning of this concept in the elderly population and thus describe and explain the phenomena that involve vulnerability and aging. Far beyond the physical impact, emotional or mental damage, the phenomenon emerges from a social and historical construction, in which different dimensions are intertwined to determine the mechanisms for coping with risks in the face of illness.

It is noteworthy that nursing has sought the application and mastery of different methodological references, in order to legitimize the profession and ensure scientific rigor. The variety and imprecision of terms used in the theoretical field support the need to apprehend and elucidate phenomena of interest, in order to fill gaps between the theoretical-philosophical field and professional practice. Thus it is observed, as a strategy for the construction of knowledge, the analysis and development of concepts, to contribute in the elaboration of theories and in the construction of the body of specific knowledge, promoting the interaction between theory and practice.

In view of the aforementioned considerations, this study raises the following question: What are the theoretical and empirical frameworks, evidenced through the Hybrid Concept Development Model, which can elucidate the analyzed concept "vulnerability of the elderly person"?

\section{OBJECTIVE}

Propose the concept of vulnerability of the elderly based on the Hybrid Concept Development Model.

\section{METHODS}

\section{Ethical aspects}

It is noteworthy that the study participants were informed about the objectives of the study, procedures involved, guarantee of anonymity, as well as the right to freedom to participate in data collection or to give up on it at any time during its completion. This research was assessed and approved by the Ethics and Research Committee of the Health Sciences Center, at the Universidade Federal da Paraíba.

\section{Study type}

Methodological study with a qualitative approach, based on the theoretical methodological framework of the Hybrid Concept Development Model. It should be noted that concept development refers to the rigorous process of bringing clarity to the definition of phenomena, generating "valid" concepts that are essential for the development and advancement of science excellence, both in theory and in practice ${ }^{(5)}$.In this study, the model selected for the development of the concept of vulnerability of the elderly was the Hybrid Concept Development Model, proposed by Schwartz-Barcott and Kim, since it proved to be adequate in elucidating a concept arising directly from conflicts experienced in clinical practice ${ }^{(6)}$.

The operationalization of the model in question consists of the interface between the theoretical analysis and the empirical data, related to the concepts, in the sense of identifying, analyzing and refining, focusing on the aspects of definition and measurement. For this, the authors suggest three phases, which can be operationalized progressively, phase by phase, or simultaneously: the initial or theoretical phase, the field work phase and the analytical phase.

\section{Methodological procedures}

Through the theoretical phase, the objective was, through the integrative literature review, to broaden the understanding of a 
specific knowledge and acquire a deep reach and understanding of it, developing a scientific foundation for the subsequent phases. Based on this assumption, the following guiding question was elaborated: What are the attributes, antecedents and consequences of the concept "vulnerability of the elderly"?

To answer this question, the following databases were listed: Bank of Theses and Dissertations of the Coordination for the Improvement of Higher Education Personnel - CAPES, Cumulative Index to Nursing and Allied Health Literature, Latin American and Caribbean Literature in Science Health, Medical Literature Analysis and Retrival System Online, SciVerse Scopus and Web of Science. In order to locate the studies, the following terms were selected, according to the vocabulary of Health Sciences Descriptors (DeCS): health vulnerablity (vulnerabilidad en salud and vulnerabilidade em saúde), aged (anciano and idoso), health of the elderly (servicios de salud para ancianos and saúde do idoso). As a reference, the terminology available in the Medical Subject Heading (MeSH): aged, vulnerable populations e geriatric health services. It is noteworthy that there was no time frame, including all studies available in the aforementioned databases.

The search for publications covered the period from November 2016 to January 2017, totalling 750 articles and 36 theses and dissertations. Then, the relevance of the titles and the reading of the abstracts were evaluated, in which 713 surveys were excluded, as they were unavailable in full or did not answer the guiding question or were duplicated. Then, the criteria of relevance and consistency of the content were highlighted, being excluded those that did not address the object of study. Finally, the sample consisted of 35 articles, theses or dissertations.

In the particular description of the fieldwork phase, it is emphasized that it aims to corroborate and refine the concept through empirical observations, extending and integrating the analysis initiated in the theoretical phase. To this end, a cross-sectional study of a qualitative character based on the Grounded Theory was established $^{(7)}$.

Finally, during the analytical phase, some steps are taken, in order to intensify and detail the fieldwork, reviewing the results in the light of the components of interest. This final analysis of the data allows to identify the antecedents, essential and consequent attributes of the concept contemplated in the literature, checking if they are in agreement or in disagreement with the phenomenon as experienced by the cases studied ${ }^{(6-7)}$. To illustrate the occurrence of the vulnerability of the elderly, a subsidized case was built on the attributes, antecedents and consequences of the studied concept.

\section{Study scenario}

The selection of the place where the data collection was carried out was done in a judicious manner, to ensure an expanded perspective on the phenomenon. It was carried out in a Center for Comprehensive Health Care for the Elderly, located in the city of João Pessoa, Paraíba. Given the complexity and breadth of the concept under development, it was decided to designate as participants in this study multiple health professionals, involved in assistance and/or in teaching and research including elderly people.

\section{Data source}

It was then assigned, as an inclusion criterion to exercise professional activity aimed at caring for the elderly for a minimum period of one year. Those who were away from their work activity were excluded from the study, either on vacation or on sick leave. Therefore, 12 health professionals were included in the research, of which 9 were nurses; 1 , social worker; 1 , physiotherapist; and 1, nutritionist. As it is a qualitative investigation, we chose to sample using empirical and theoretical saturation.

\section{Data collection and organization}

Data collection took place between March and August 2018, through semi-structured interviews with questions relevant to the objective of the study. Using the technique of focused interviewing, a script was applied with the main topics to be addressed, considering the different perspectives on the phenomenon, with individual, social and programmatic issues. Data collection was maintained until all categories proved to be well developed in terms of properties and dimensions, without showing new or relevant data for the study.

As a theoretical-methodological framework, Grounded Theory was used, in which the hypotheses of the study are created in the course of data analysis and, when compared throughout the research process, can be confirmed, extended, modified or disregarded. After the analysis of the speeches, the generated codes were classified in attributes, antecedents and consequences of the studied phenomenon.

\section{RESULTS}

The final analytical phase comprises the comparison between the data that emerged during the theoretical analysis and the empirical observations, supporting the presentation of the definition of the concept, as well as the recognition of possible conceptual gaps. By making the interface between theoretical and empirical data, it became possible to identify whether the components of the concept (antecedents, attributes and consequences) are similar or different, thus facilitating a greater understanding of the phenomenon.

It is verified that the vulnerability of the elderly person presents itself through individual and social aspects. In the theoretical survey, scientific evidence allowed to verify that the referred phenomenon has, as main physical and individual characteristics, reduced coping capacity, comorbidities, cognitive impairment and decline in functional capacity. In the social sphere, race and living in risk areas are evident as attributes to the elderly with vulnerability.

When analyzing the professionals'speeches, issues regarding decreased defence capacity, passivity in face of events, susceptibility to injuries, high prevalence of chronic diseases, decreased cognitive domains and reduced daily activities predominated. Although there is theoretical and empirical agreement between most attributes, it is worth noting that some characteristics that were evidenced in the empirical phase were not present in scientific literature, as shown in Figure 1. 


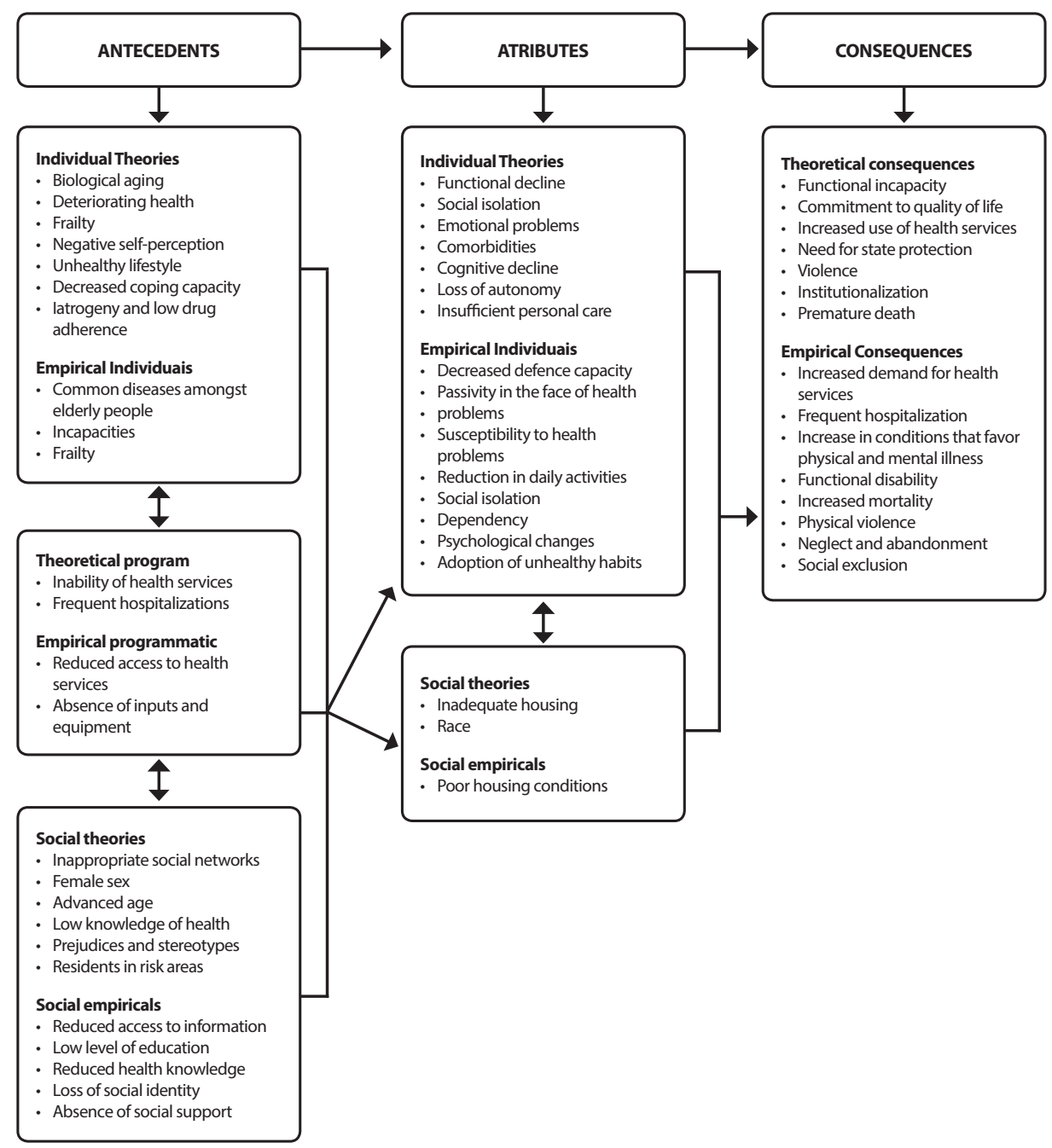

Figure 1 - Synthesis of the elements of the concept "vulnerability of the elderly", according to the literature and empirical evidence, João Pessoa, Paraíba, Brazil, 2019

With regard to the situations that precede the occurrence of the phenomenon, the individual, programmatic and social aspects stand out. Among the theoretical background, negative self-perception of health, health deterioration, biological aging, frequent and prolonged hospitalizations, the inability of health services, low health knowledge and population aging were indicators observed in the analysis of studies scientific. As for the speeches expressed by the study participants, it has highlighted the disabilities resulting from advancing age, limited health care and the lack of family and social support, which emerged as important antecedents for the vulnerability of the elderly.

Regarding the consequences of the phenomenon studied, the following were found among the theoretical data: increased use of health services, impaired quality of life, functional disability, institutionalization and premature death. It is worth mentioning that, although the empirical evidence is in line with that found during the theoretical analysis, social exclusion, neglect and abandonment, as well as the increase in conditions that favor physical and mental illness, were only recurrent in the speeches.

\section{Concept development}

Based on the results, the conceptual analysis made it possible to clarify the definition of the phenomenon, described as follows: the vulnerability of the elderly person is a multifaceted construct, in which individual and collective conditions interact with each other, determining the reduction of the capacity to cope with health problems. Due to a complex interdependence between biological, social and programmatic determinants, the elderly person may experience a progressive decrease in the resources needed to maintain an autonomous, safe life, as well as preserved physical and mental health ${ }^{(8)}$.

\section{Case}

Once the components and the definition of the vulnerability of the elderly person are presented, a case is described, constructed based on the outline of the essential elements of the concept, such as attributes, antecedents and consequences, evidenced in the theoretical and empirical phases. Thus, the following is a representation of the studied phenomenon:

M.L.F., 80 years old, black, female, Brazilian, single, retired, receives a monthly minimum wage, living in a peripheral community in the city of João Pessoa (PB), lives in a three-room house, without basic sanitation and running water. She lives alone, receives a visit once a month from a niece, who helps her buying groceries and medicines. Regarding the family, she has a single daughter who resides in another state. Illiterate, she took care of domestic activities in a family home until she was approximately 55 years old, when she began to experience difficulties in carrying out the tasks. Refers diagnosis of hypertension and diabetes mellitus for about five years. Although she recognizes such morbidities, she declares that she does not perform physical activities or adopt healthy eating habits, in addition to routinely forgetting to use the prescribed medication. She also complains of recurrent pain in the body, especially in the joints, a condition that is secondary to osteoarthritis, which causes her to limit activities at home. She does not frequent community spaces, such as social groups or churches, because she believes that her poor health condition does not allow her to carry out activities outside her home. Recently, due to muscle weakness and gait instability, she suffered a fall episode when traveling by bus to the specialized health center, since the basic health unit in her area had been disabled due 
to poor physical structure conditions. This episode resulted in a fracture of the femoral neck, which required surgical correction. In addition, the immobility in the bed generated a pressure injury in the sacrococcygeal region, which required specific and prolonged treatment, with admission to the hospital unit. She states that, although the $\mathrm{BHU}$ has returned to its activities, it never received home visits from the health team, using the service only to access the medications. She prefers not to go to the health service for fear of a new accident and for not being able to meet the care demands guided by the professionals, thus choosing to do what they think is correct. For a year, she has had difficulty making purchases and paying bills, due to the inability to manage her financial resources, being at the mercy of the solidarity of third parties. She claimed that she was assisted by a formal caregiver, but suffered physical and patrimonial violence, and has remained alone at home ever since. Such limitations concern her daughter, who reports changes in her mother's mood, such as sadness and discouragement, due to her physical and cognitive limitations. However, she points out that, despite the concern, she cannot be responsible for the care, thinking about looking for a long-term institution that can keep the mother safe and healthy.

\section{DISCUSSION}

When reviewing the results, it becomes possible to answer the questions that guided the development of the research. Considering this, it is emphasized that the concept "vulnerability of the elderly" proves to be applicable and important for health practices, since, due to the marked demographic aging, there is a need to recognize the individual and collective demands of this population segment, discussing and implementing health interventions in a comprehensive and resolutive manner. Through theoretical deepening and empirical evidence, knowledge about the phenomenon was expanded in all its complexity, outlining the aspects that precede its occurrence, its manifestations and consequences for the population studied.

Therefore, it was possible to assess the problem of vulnerability and its relationship with human aging, with regard to biological decline associated with unfavorable social conditions, unhealthy lifestyle and reduced access to health services. It is worth mentioning that the presence of the phenomenon in question can cause adverse health outcomes and, consequently, impact the quality of life, as evidenced in the theoretical and empirical analyzes contemplated in this study.

It is known that biological and chronological aging is a natural and inevitable process, in which an accumulation of molecular damage is evidenced throughout life, resulting in the gradual increase of defective cells and metabolic changes. The deleterious effects over the years interfere with the performance and quantity of functional tissues in different organs, being then responsible for the prevalence of diseases, especially neurodegenerative ones, and for the restriction of functional capacity ${ }^{(8-9)}$.

Multimorbidity, in which there are two or more chronic diseases in the same individual, is associated with the negative outcomes of human aging, especially with high mortality rates. As it is the most evident change, the prevalence of diseases among the elderly population favors the cultural conception of the human aging process, in which there is inevitably an accumulation of physical and cognitive diseases, as well as weaknesses. However, this stage of life should not be synonymous with morbidities, even when it culminates in the progressive loss of functions and severe limitations, as it is a period with its own characteristics and values ${ }^{(10)}$.

As a result, the quality of life of the elderly is compromised, mainly due to acquired functional disabilities, which tend to facilitate institutionalization, the occurrence of violence and premature death. It becomes necessary to recognize multicausality in the decline in functional capacity. In addition to biological influences, such as heart disease, diabetes, high blood pressure and Parkinson's disease, social determinants stand out as predisposing to this phenomenon. Research shows that lower social engagement, the absence of support networks and low socioeconomic status predict functional and cognitive decline, as well as a higher occurrence of chronic and infectious diseases ${ }^{(11)}$.

In addition to the biological aspects, there is a change in their role in society, scarce financial resources, the lack of social and family networks that favor vulnerability. Negative stereotypes are frequent among the elderly population, such as family abandonment, loneliness and social isolation, which are important demands and require differentiated care.

Studies claim that loneliness, depression and suicidal ideation are more recurrent in older people, women and among those who experience the end of a relationship or widowhood. Even when the elderly person has adequate family support, it is essential that they participate in activities in the community, remaining physically and psychically active ${ }^{(4)}$.

With population aging, the demand for public services becomes more and more present. However, meeting the diverse needs of the elderly population constitutes one of the great challenges of Unified Health Service SUS, since, even without chronic diseases, they may present some functional loss. The articulation of the lines of comprehensive care, through the organization of health services, is essential for the provision of health care based on resolving the demands of users ${ }^{(2)}$.

However, health services fragment the care for the elderly, with isolated consultations with several specialists, absence of reference and counter-reference, numerous drugs, the need for clinical and imaging tests, among other specific procedures. Such conduct overloads the system, causing an important financial impact on all levels of care in the SUS service network. With the care model based on the disease, it becomes a challenge to anticipate health problems and minimize functional decline, thus generating significant benefits for the health of the elderly ${ }^{(1)}$.

Recognizing the elderly in the face of their multiplicity is one of the strategies listed to bridge possible gaps in the care provided. Therefore, it is increasingly necessary to consider the complexity inherent to the biological, social and psychological aging processes, which interact with each other and determine the heterogeneity of senescence. The elderly person must be seen individually, in order to identify how the physical, mental, social conditions, economic and functional resources determine their real demands and influence the quality of life ${ }^{(10-13)}$.

By recognizing the individual and collective needs of the elderly population, it is possible to understand the different dimensions 
and specificities that influence the health-disease process. From this perspective, authors emphasize that it will be up to health professionals to add this knowledge to care practices, through a comprehensive care plan that incorporates social, programmatic and individual aspects ${ }^{(14)}$.

Recognizing the characteristics of vulnerability in the elderly is essential to advance the understanding of the phenomenon, especially because it has a dynamic and multifaceted nature, influenced by individual and collective behaviors accumulated throughout life. The decrease in the capacity to cope with health problems threatens autonomy; and the decrease in the elderly person's potential increases the feeling of vulnerability as well as intensifies functional disabilities and dependence. The loss of power, evidenced by the biological and social changes resulting from senescence, puts integrity at risk and minimizes potentialities, increasing the feeling of vulnerability, already experienced with advancing age.

The knowledge acquired about the phenomenon provides tools for professionals to assist the elderly and assist in the elaboration of intervention strategies that stimulate their autonomy and coping skills. The theoretical and empirical evidence verified allows the adequacy of health policies and programs, aiming at the promotion of care, disease prevention and comprehensive health care for the elderly, reducing vulnerability in this population group.

\section{Study limitations}

Among the limitations of this research, it is highlighted that the empirical phase was carried out only with health professionals, due to the difficulties evidenced in addressing the phenomenon with the elderly. The dynamism of the concept allows it to be subject to change as it is used in different contexts. Therefore, the importance of constantly applying, testing and refining the concept of vulnerability of the elderly is emphasized.

\section{Contributions to the area}

The concepts come from clinical practices, so empirical observations have an important role to outline their development, as well as to organize knowledge and expand nursing praxis. Thus, the concept proved to be relevant and applicable for the care of the elderly, as it is a real and visible phenomenon among the population studied, as evidenced in this article.

With this understanding, it is emphasized that the results obtained through this study represent relevant elements, as they contribute to the reflection on the part of health professionals about the need to plan actions that can early recognize the vulnerable elderly and, in a way, build care strategies that can outline methods for early detection and monitoring of installed disabilities.

\section{FINAL CONSIDERATIONS}

The present study enabled the development of the concept of vulnerability of the elderly, based on the dialogue between the theoretical components and the empirical evidence, collected from the experiences of health professionals who perform work and research activities with the elderly population.

Despite being commonly used in the field of health, the concept proved to be broad, complex and subjective, since there is no consensus in the literature regarding the referred phenomenon, thus evidencing different generic and incipient definitions that do not consider the specificities of the elderly person.

It is noteworthy that vulnerability is seen as a multidimensional construct, in which behavioral, socio-cultural, economic and political conditions interact with biological processes throughout life. Therefore, it is opportune to highlight the need for more in-depth studies on the understanding of the concept, such as the present study, allowing its clarification in order to provide elements for its practical applicability to the needs of the elderly.

The theoretical and empirical elucidation of the characteristics of vulnerability allowed us to list, as antecedents of the phenomenon, negative self-perception, health deterioration, biological aging, unhealthy lifestyle, frequent and prolonged hospitalizations, inability of health services, as well as low knowledge on health, scarce financial resources and inadequate social networks.

Regarding the attributes, it was found that vulnerable elderly people may have reduced coping capacity, high prevalence of chronic diseases, cognitive impairment, decline in functional capacity, social isolation, loss of autonomy, in addition to living in risk areas, with little infrastructure and poor access to health services. Furthermore, as a consequence of the phenomenon, one can list the impairment of quality of life, premature death, institutionalization and, finally, functional disability, which favors the social exclusion of the individual.

The interface between theoretical and empirical data enabled the definition of the vulnerability of the elderly through the recognition of the attributes, antecedents and consequences of the phenomenon. This definition was then shown as a multifaceted construct, in which individual and collective conditions interact with each other, determining the reduction of the capacity to cope with health problems.

Outlining the concept, carried out here, allows answering the questions emerging from the health of the elderly population, recognizing the gaps and supporting the practical application of the knowledge acquired in theoretical research. Therefore, by identifying the attributes, antecedents and consequences of the vulnerability of the elderly, it is possible to carry out empirical research in order to test, modify or expand the concept, thus contributing to the advancement in Nursing science.

\section{REFERENCES}

1. Veras RP, Oliveira M. Aging in Brazil: the building of a healthcare model. Ciên Saúde Coletiva. 2018;23(6):1929-36. doi: $10.1590 / 1413-81232018236.04722018$

2. Barbosa KTF, Costa KNFM, Pontes MLF, Batista PSS, Oliveira FMRL, Fernandes MGM. Agind and invidual vulnerability: a panorama of older adults attended by the family health strategy. Texto Contexto Enferm. 2017;26(2). doi: 10.1590/0104-07072017002700015 
3. Santos VP, Lima WR, Rosa RS, Barros IMC, Boery RNSO, Ciosak SI. Perfil de saúde de idosos muito velhos em vulnerabilidade social na comunidade. Rev Cuid. 2018;9(3):2322-37. doi: 10.15649/cuidarte.v9i3.542

4. Cardona D, Segura A, Segura A, Muñoz D, Jaramillo D, Lizcano D, et al. Indice de vulnerabilidade de adultos mayores en Medellín, Barranquila y Pasto. Biomedica. 2018;38:101-13. doi: 10.7705/biomedica.v38i0.384

5. Chinn P, Kramer M. Integrated theory and knowledge development in Nursing. 8th ed. St Louis: Elsevier; 2011.

6. Schwartz-Barcott D, Kim HS. An expansion and elaboration of the hybrid model of concept development. In Rodgers BL, Knafl KA. Concept development in nursing. Philadelphia: Saunders; 2000. 129 p.

7. Fernandes MGM, Nobrega MML, Garcia TR, Costa KNFM. Análise conceitual: considerações metodológicas. Rev Bras Enferm. 2011;64(6):1150-6. doi: 10.1590/S0034-71672011000600024

8. Barbosa KTF. Vulnerabilidade da pessoa idosa: desenvolvimento do conceito [Tese]. João Pessoa (PB): Universidade Federal da Paraíba; 2019.

9. Sgarbieri VC, Pacheco MTB. Healthy human aging: intrinsic and environmental factors. Braz. J. Food Technol. 2017;20:1-14. doi:10.1590/1981-6723.00717

10. Nunes BP, Batista SRR, Andrade FB, Souza Jr PRB, Lima-Costa MF, Facchini LA. Multimorbidade em indivíduos com 50 anos ou mais de idade: ELSI-Brasil. Rev Saúde Pública. 2018;52(Suppl 2). doi: 10.11606/s1518-8787.2018052000637

11. Wallace LM, Theou O, Pena F, Rockwood K, Andrew MK. Social vulnerability as a predictor of mortality and disability: cross-country differences in the survey of health, aging, and retirement in Europe (SHARE). Aging Clin Exp Res. 2015;27:365-72. doi: 10.1007/ s40520-014-0271-6

12. Ferreira ACS, Mattos M. Multiprofessional care for the elderly in a chronic condition in the family health strategy. Rev Bras Promoç Saúde [Internet]. 2018 [cited 2019 Nov 19];31(3):1-10. Available from: https://periodicos.unifor.br/RBPS/article/view/7576/pdf_1

13. Ferreira BR, Silva FP, Rocha FCV, Oliveira ADS, Amorim FCM. Elderly Welcoming in Primary Health Care: The User Perspective. Rev Pesqui: Cuid Fundam. 2018;10(3):669-74. doi: 10.9789/2175-5361.2018.v10i3.669-674

14. Bolina AF, Rodrigues RAP, Tavares DMS, Haas VJ. Factors associated with the social, individual and programmatic vulnerability of older adults living at home. Rev Esc Enferm USP. 2019;53:e03429. doi: 10.1590/S1980-220X2017050103429 